Island Studies Journal, Vol. 9, No. 1, 2014, pp. 103-122

\title{
The role of the political system in shaping island nationalism: a case-study examination of Puerto Rico and Newfoundland.
}

\author{
Valérie Vézina \\ PhD candidate, Université du Québec à Montréal \\ Canada \\ valerie.vezina@gmail.com
}

\begin{abstract}
Islands are sites where specific forms of governance can develop, providing insights for 'continental' nations. This paper discusses the role the political system has in shaping nationalist policies and demands in island settings, examining the specific cases of Puerto Rico and Newfoundland. Starting from a hypothesis outlined by both Fazi and Hepburn, this paper aims at finding empirical data and evidence to the hypothesis that island jurisdictions having a different party system than their central state show an increase in their nationalist demands. In order to do so, this paper first examines the definition of island nationalism and offers, following Lluch's typology, a framework for analyzing nationalist demands. Then, it examines important historical material in both Newfoundland and Puerto Rico. This will demonstrate how political parties and political leaders can use nationalism to shape policies and will allow us to verify the initial hypothesis.
\end{abstract}

Keywords: islands; nationalism; Newfoundland; political leaders; political parties; political system; Puerto Rico

(C) 2014 - Institute of Island Studies, University of Prince Edward Island, Canada.

\section{Introduction}

Islands have been studied and celebrated in literature, biology, anthropology and politics for many years; and the study of the relationship between islandness and nationalism goes back at least to the musings of Rousseau (1765) on Corsica. In the study of island nationalism in particular, there is some agreement that some key circumstances can enhance nationalist sentiments, be they economic, geographical or political. The recent works of André Fazi (2012a; 2009) and Eve Hepburn (2012) with regards to island jurisdictions offer interesting avenues and hypotheses on nationalist demands to be yet complemented by empirical data. Both Fazi (2012a, p. 147) and Hepburn (2012, p. 129) argue that having a suite of political parties on an island jurisdiction that is different from that which prevails on the central state would lead to increased nationalist demands, irrespective of whether these can be qualified as autonomist or independentist. Hepburn (ibid.) even suggests that "the existence of one or several nationalist parties seeking self-determination leads to demands for a stronger degree of autonomy." Although both authors outlined a series of hypotheses referring to the various dimensions of islandness, which we will examine later, none provide substantial empirical evidence. Their frameworks hence need to be tested empirically. This paper is a first step towards such an attempt. Our goal is not to provide evidence for each dimension of islandness, but to focus on the political dimension and the specific hypotheses attached to it. 
In order to do so, a comparative approach has been chosen. Our focus will be on Puerto Rico and Newfoundland ${ }^{1}$. Despite a few differences - as in language, about which more below - both islands share some common features. Both islands are subnational jurisdictions that form part of larger, federal states (USA for Puerto Rico, Canada for Newfoundland). As studies on federalism have shown (Watts, 2008), federal-type unions tend to allow a greater share of power among units, which, in our case, can be of interest in regards to nationalist demands. Both islands have a strong identification to their nation (Ryan Research, 2003, p. 397; Vézina \& Basta, 2014, pp. 73-74 for Newfoundland; Morris, 1995, p. 76 for Puerto Rico). Both islands have obtained their current status practically at the same time: Estado Libre Asociado for Puerto Rico in 1952 and provincial status for Newfoundland (along with Labrador) in 1949. This choice, in both islands, has been voted for by the population through referenda. Both islands have high levels of emigration towards the continent. Both islands display strong cultural nationalism, through a rich and distinct culture with local traditions and symbols (such as flags, national anthems, dishes). All those similarities, despite the differences in geographical location, surface area, and population, makes us think that a suitable comparison is possible between these two islands. Most importantly and in relation to our thesis, the party system is different. In Newfoundland, the provincial party system is similar to the federal level; but Puerto Rico has its own party system, unlike what is found in the USA.

In this paper, we will first define island nationalism, by looking at both islandness and nationalism with the idea of specifying the various types of nationalist demands. This will lead us to (re)formulate Fazi's and Hepburn's hypothesis regarding the political system. Then, we will look at the case of Newfoundland and see how nationalism has been promoted throughout the years. Next, we consider the case of Puerto Rico and how the political party system there has helped to spur nationalism in the context of an extended discussion over the island's status. We will then offer a comparison which will allow a return to, and re-examination of, our initial hypothesis.

\section{Island nationalism}

In order to argue that Puerto Rico and Newfoundland exhibit nationalism, it is important to assess how we conceptualize island nationalism. In order to do so, we need to reconcile the concept of islandness with the theory of nationalism. In doing so, we can establish a theoretical framework - namely, island nationalism - that can be generally applied to any island, whether or not it is attached to a central state.

Islandness is a concept that applies to the distinctive character and features of islands. Islandness is "an intervening variable that does not determine, but contours and conditions physical and social events in distinct, and distinctly relevant, ways" (Baldacchino, 2006, p. 9). For Philip Conkling, islandness is a phenomenon that researchers and non-islanders try to define, comprehend, and acquire, but that islanders instinctively understand (2007, pp. 191192). Eve Hepburn (2010, p. 10) identifies six dimensions to the concept of islandness: geographical (separation from mainland); political (expressed through a desired to be selfgoverning); social (a sense of islander identity); demographic (high rates of emigration);

\footnotetext{
${ }^{1}$ The province of Newfoundland and Labrador will be referred to here as Newfoundland. With reference to island nationalism, we are interested in the island component of the province only, namely Newfoundland. A different form of nationalism exists in Labrador, where Labradorians feel that the development of the province's natural resources benefits the island, but not necessarily them. This could be the subject of future research.
} 
historical (as sites of conquest, assimilation and colonialism); and economic (limited resources, absence of economies of scale and high transportation costs). Accordingly, islandness seems to play a decisive role in the development and construction of a distinct national identity. The geographical condition of islandness helps to define the basis of distinctiveness in island settings. Despite the operationalization offered by Hepburn, islandness remains a phenomenon whose implications can be 'felt'. Such feelings of distinctiveness, one can argue, could spur nationalist sentiments. Hence, the focus of this paper is on the political aspect of island life. Fazi and Hepburn, as noted above, have formulated various hypotheses in relation to autonomy. According to us, before talking of 'autonomy' or 'autonomous demands', it is important to define nationalism and outline what are the various types of nationalist demands. In order to do so, we will draw upon a constructivist approach à la Brubaker and on the work of Jaime Lluch $(2011 ; 2012)$ regarding nationalist demands.

Nationalism as a concept has been widely studied. Its relationship with territoriality, and islands in particular, has also led to numerous studies on island states, such as Britain for example (Colley, 1992; Greenfeld, 1992). Others (Baldacchino, 2010, 2004; Baldacchino \& Hepburn, 2012) have studied this phenomenon in relation to non-sovereign island jurisdictions. For Baldacchino, this takes the form of island subnationalism, which he explains as follows,

The articulation of nationalism [in island settings] is becoming jurisdictional ... Many island people are comfortable in displaying evidences of sub-nationalism, much like a regional or geographically anchored ethnicity (Baldacchino, 2004, p. 79).

Baldacchino's conceptualization is useful and, for the purpose of the argument here, will be combined with Rogers Brubaker's 'practical category'. For Brubaker,

Nationalism is not a 'force' to be measured as resurgent or receding. It is a heterogeneous set of 'nation'-oriented idioms, practices, and possibilities that are continuously available or 'endemic' in modern cultural and political life. ... My concern ... is not with the resurgence but with the reframing of nationalism, not with how much nationalism there is but with what kind, not with the strength but with the characteristic structure and style of nationalist politics (Brubaker, 1996, p. 10).

In other words, Brubaker is arguing that measuring nationalism is of little intrinsic interest. Instead, we need to understand the form nationalism takes in a certain place and the practices and circumstances (whether political, economic or social) that led to that particular form. With this ambition in mind, it is possible now to bring forward the concept of island nationalism. From our perspective, island nationalism applies to islands that possess the six dimensions of islandness as previously provided by Eve Hepburn and where political practices and circumstances have led to the expression of nationalism.

That being said, nationalism can vary widely within a nation and a national movement. The work of Jaime Lluch in that regard is enlightening. His work is part of a desire to distance himself from the idea that the final goal of any national movement is independence,

Variation in secessionism is also interesting because separatism 'is widely held to be the culmination of national development, the peak manifestation of nationalism, reflecting a nation's collective desire to establish or protect its own state in the international arena, 
one that is equal or superior in status to all other state...' (Hale, 2003, p. 3) Yet, we find many sub-state nationalists that opt for a variety of non-secessionist orientations (Lluch, 2012, p. 434).

For Lluch, studying such variation is worthy of knowledge and leads to three main orientations which can lead, or not lead, to sovereignty,

[T] he national movements of "minority nations" are internally differentiated, and the political tendencies (that is, political parties) making up sub-state national movements are subdivided into two or three basic political orientations: pro-independence, proautonomy, and, in some cases, pro-federation. Moreover, the internal currents within national movements can vary over time, experiencing moments of foundation, growth, development, and decay (Lluch, 2011, p. 204).

As he reminds us elsewhere,

these [independentists, autonomists, federalists] are competing forms of nationalism: they all agree that the nation exists but they disagree on the degree of sovereignty the nation should seek (Lluch, 2012, p. 435).

By keeping in mind this distinction - albeit there may very well be differences within each of these three groups - we can still formulate our hypothesis along the lines of Fazi and Hepburn. We thus make the assumption that an island jurisdiction where a different party system exists and offers the three political orientations (independence, autonomy, federation) will exhibit a stronger degree of nationalist demands (of all forms) compared to an island where the party system is similar to the continental state. To verify such a hypothesis, we will now turn to each case study by examining key historical and political events with regards to nationalism. This will allow us to examine how nationalism has been spurred in both island territories.

\section{Newfoundland: a nation in search of an identity}

\section{From glory to downfall: Newfoundland's unique historic route}

A strong sense of local identity was an important reason why Newfoundland rebuffed opportunities to join Canada until 1949. Two Newfoundland delegates attended the 1864 Quebec Conference, but the fiscal arrangements and the centralized character of early Canadian federalism made Newfoundlanders sceptical of union with Canada. In the 1869 election, the topic of Confederation ran throughout the campaign, but anti-Confederates won a majority of seats (Penney, 1981, p. 12). Initiatives for a union with Canada were thus shelved for decades, but in 1894-95, owing to a financial crisis in Newfoundland, the Confederation option came back to the table. As a precondition to joining Canada, the government of Newfoundland demanded the assumption of its debts by the Canadian government, but Canada refused. Because of a lack of agreement on financial terms, Newfoundland decided once again against Confederation (ibid.). Newfoundland's political autonomy grew in 1907 when it became a semi-autonomous Dominion. However, after World War I and the decline of the fishing industry during the subsequent global economic crisis, the Dominion entered a 
precarious financial position. Unable to meet the interest payments of the public debt (then valued at US\$98.5 million) (Baker, 2003, p. 33), a Newfoundland Royal Commission (the Amulree Commission) recommended "that the 1855 constitution be suspended. ... Faced with the unpalatable alternative of default, on November 28, 1933 the Dominion of Newfoundland requested the British Government to replace the existing elected government by an appointed Commission" (Baker, 2003, pp. 33-34). A Commission of Government was established on February 16, 1934 and assumed full governmental responsibilities until 1949.

Two referenda on Newfoundland's political future were held in the summer of 1948. The first was held on June $3^{\text {rd }}$ and contained three options for voters: the continuation of the Commission of Government, responsible government, or Confederation. After the ballots were counted, although responsible government won (with $44 \%$ of the votes), the result was not enough for a clear majority. Hence, a second referendum was to take place with two options on the ballot: responsible government or Confederation (the 'Commission of Government' was dropped from the ballot, having received only 14\% support in the first referendum). On July $22^{\text {nd }}$, Newfoundlanders voted to join Confederation. The results were close: 7,000 votes separated the two options. The Confederation option gained 78,323 votes (52.3 percent) and responsible government received 71,334 votes (47.7 percent). One minute before midnight on March $31^{\text {st }} 1949$, Newfoundland officially became the $10^{\text {th }}$ Canadian province. English was and remains the main spoken and written language, in both the province and Canada as a whole. In part, as a consequence of the late accession of Newfoundland to Canada as well as a long period of separate political existence, Newfoundlanders have traditionally demonstrated weak attachment to Canada (Young, 2003; Vézina \& Basta, 2014).

\section{Nationalist rhetoric: a powerful tool for Premiers}

Before going into further analysis, it is worth noting that Newfoundland's party system is similar to the one found at the Canadian federal level. Similarly to the federal level, since Newfoundland joined Confederation, power has been shared between the Liberal party and the Progressive-Conservative Party (PC) (with an increase, in recent years, of popular support for the New Democratic Party). Although the provincial Liberals and the PCs claim to be different than their federal counterparts, the overall party system and ideological bent remain similar. That being said, nationalist rhetoric in Newfoundland has mainly taken the form of "Ottawabashing" and can be found among leaders from various political allegiances. For Cadigan (2009, p. 296),

[s]ince Confederation, politicians have used a particular form of neo-nationalist Ottawa-bashing to distract the people of Newfoundland \& Labrador from the failures of provincial policies and to co-opt their support.

There are various examples of such "Ottawa-bashing". In 1959, after disagreements with Prime Minister Diefenbaker on Term 29 of the Terms of Union, which stipulated that a royal commission would advise on additional financial assistance to the province, Newfoundland Liberal Premier Joey Smallwood proclaimed three days of mourning during which all flags were flown at half-mast and the doors of provincial government buildings were draped in black. Smallwood was convinced that Newfoundland's exceptionalism with respect to federal fiscal arrangements had to be secured, whereas the Progressive Conservative Diefenbaker 


\section{Vézina}

government opposed individual deals with provinces, preferring a regional approach to economic development (Cadigan, 2009). In 1982, Brian Peckford, a Progressive Conservative, took similar actions: when negotiations with Prime Minister Trudeau's Liberal government over offshore oil ownership broke down, he asked all members of the legislature to wear black as a sign of mourning. Peckford was able to sign the Atlantic Accord in 1985. The Accord was of crucial importance on both an economic and nationalistic level:

The Accord, which affords to Newfoundland rights to all revenue flowing from offshore oil development as if the resource were within provincial boundaries onshore, as well as equal rights with Canada in the management of offshore resource development, is certainly unique in Canadian federal-provincial relations and pivotal in the history of Newfoundland's long struggle to gain some say in the exploitation of its natural wealth (Jackson, 1986, p. 107).

In short, Peckford's years were characterized by federal-provincial conflicts over natural resource ownership, fisheries management, and hydro development. Peckford argued for a decentralization of Canadian federalism and Newfoundland's autonomy from Ottawa in the development of the province's rich resource endowment. As Summers argues: "Peckford's political rhetoric stressed a pride in Newfoundland and was accompanied by a call for increased powers for the provincial state" (2001, p. 37). This period ended when Peckford lost power, as he was followed by a series of leaders (Wells, Tobin) who advocated for a strong, centralized federal government.

In 1992, the federal government announced the closure of the northern cod fishery. The moratorium put some 20,000 fishers and plant workers out of work, and triggered what has been described as one of the largest industrial layoffs in Canadian history.

For more than 400 years, the groundfish fishery has sustained Newfoundland and Labrador. Under federal control, this great resource has been brought to the brink of extinction ... this environmental, social, and economic tragedy occurred on the federal government's watch and as a result of its failure to manage the resource properly (Young, 2003, p. 72).

This event left a bitter taste to most Newfoundlanders, who felt betrayed by the federal government. The government was seen as taking away a part of their pride, their main source of livelihood and, most importantly, their national identity.

The $21^{\text {st }}$ century brought winds of change to Newfoundland politics. With the election of the Progressive Conservatives (who had not been in power for almost 15 years) and Danny Williams as Premier, relations with the federal government, industries, and the other provincial governments changed dramatically. Newfoundland's new mantra became 'no more giveaways' in regards to its natural resources. When we look back at Williams' two terms in office from 2003-2010, there are a number of examples that illustrate why he was often depicted as the 'man for whom no battle was too small.' Of particular interest is the renegotiation of the Atlantic Accord, because it illustrates how Newfoundland was able to ask for control over natural resources. 
As discussed earlier, in 1985, the federal and provincial governments entered into an agreement, known as the Atlantic Accord, which provided for the joint management of offshore petroleum resources and the sharing of revenues. Paragraph 2(c) of the Accord recognizes Newfoundland and Labrador as the principal beneficiary of any oil and gas resources off its shores. However, ever since the Hibernia oilfield came on stream, this has been a contentious issue. As argued by the Chair of the Royal Commission Report on Renewing and Strengthening Our Place in Canada, "the federal and provincial governments [should] enter into immediate discussions to revise the Atlantic Accord to ensure that the principalbeneficiary objective is both honoured and achieved" (Young, 2003, p. 122); a goal that Premier Williams actively pursued. By early 2005, Williams was able to convince the federal government and Prime Minister Paul Martin to create a 'new' Atlantic Accord to compensate the province for lost revenue (Marland, 2007, p. 76).

However, the discussions with the federal government about offshore revenues were not satisfying to the Premier. Henceforth, Williams threatened to remove all Canadians flags from provincial government buildings if the federal government was not ready to fulfil its promise to negotiate with the province. On December 23, 2004, he stated,

The federal government has turned its back on the people of this province and we will not accept less than what was committed to by the prime minister and to what we deserve (CBC News, 2004).

The Canadian flags duly disappeared from public buildings throughout the province. Williams never backed away from his position and was able to negotiate a favourable deal for Newfoundland and Labrador: a Can\$2-billion agreement, allowing the province to keep both its offshore energy revenues and its equalization payments as a 'have-not' province (Baldacchino, 2009).

However, the election of Stephen Harper and the Conservative Party in 2006 clouded this accomplishment. A new conflict arose between the federal government and the province of Newfoundland regarding the enforcement of certain clauses in the 2005 Atlantic Accord. Unwilling to enforce the Accord, Prime Minister Harper and the Conservatives were not able to win a single seat in the province in the 2008 federal election, mainly due to Williams' ABC ("Anything but Conservative") campaign. The message sent to the federal government was clear: the province will not elect Conservatives unless Harper negotiated with Williams in good faith.

What is particularly interesting in these examples is Williams' ability to rally a broad local constituency in the fight for what he presented as the province's deserved rights. By using statements such as "the federal government has turned its back," and "what we deserve," Williams was able to generate the impression that the federal government was not accountable towards the people of the province and that it should be taken to account for this dismissal. But most importantly, Williams effectively appealed to Newfoundland's sense of pride and sense of belonging. Such language shows how the nation was called upon to put its faith behind its leader and how that leader used that faith to promote his ideals for the province. 
As Jerry Bannister has pointed out, the use of nationalist rhetoric is not new in Newfoundland,

[Nationalist rhetoric]'s essential logic has remained basically the same for almost two centuries: Newfoundland has a poor economy but is rich in natural resources; its poverty is due to incompetent resource management by state agencies based outside the island; local authorities have superior technical expertise, moral commitment, and popular legitimacy; the absence of proper policies and administration is caused by the lack of sufficient local control over resource exploitation and allocation; thus the key to prosperity is the transference of power to local political institutions. Nationalist ideology contains three primary ingredients: a version of history constructed to support its aims; an assertion that the panacea for historic economic problems is to adopt a new political system; and a conviction that progress can be made only by increasing local autonomy (Bannister, 2003, p. 147).

As we have seen from our analysis of circumstance and practice, nationalism in Newfoundland can and does exist; it manifests itself in demands for more autonomy, especially regarding ownership of natural resources. However, it has not manifested itself in a distinctive and separate political party system.

\section{Puerto Rico: the political party system and the status question}

Puerto Rico provides a similarly interesting though different case study. Under Spanish authority for four centuries, Puerto Rico was ceded to the United States (US) as a result of the Spanish-American War in 1898. In this section, we detail some of the laws and political events that have impacted on the politics of the island, providing a brief introduction to the Puerto Rican question.

In 1900, under the Foraker Act, Puerto Rico was entitled to only one delegate in the US Congress: a Resident Commissioner, with voice but no vote. As Roland Perusse explains,

Only much later was he [the Resident Commissioner] given a vote in committees to which he was assigned (1990, p. 17).

The Jones Act of 1917 granted a bill of rights and US citizenship to the people of Puerto Rico and the provision for an elected Senate. It was not until 1947 that federal legislation was amended to allow Puerto Ricans to elect their own governor. In 1948, Luis Muñoz Marin became the first elected governor of Puerto Rico. Muñoz Marin and the Popular Democratic Party $(\mathrm{PPD})^{2}$ created the unique Commonwealth arrangements through which Puerto Rico enjoyed considerable political autonomy while remaining under American sovereignty (LeDuc, 2003). In 1952, legislation enacted by the US Congress (Public Law 447 and Public Law 600) granted Puerto Rico the authority to establish a form of local government through a constitution approved by the citizens of Puerto Rico and the US Congress. A referendum was held in Puerto Rico on March 3, 1952 and the constitution was approved by more than $80 \%$ of the Puerto Rican electorate, though less than $55 \%$ of eligible voters participated in the plebiscite (Pantojas-

\footnotetext{
${ }^{2}$ The English names of Puerto Rican political parties have been used here; however, the acronyms reflect the Spanish names, for consistency with most of the literature on Puerto Rico.
} 
García, 2013, p.44). The constitution was proclaimed into effect on July 25, 1952 by Governor Muñoz Marin. Puerto Rico remains subject to congressional jurisdiction today under the Territorial Clause of the US Constitution. Since 1952, the Commonwealth of Puerto Rico and the particular relationships it has with the US has remained more or less the same. Under the Commonwealth status,

... residents of Puerto Rico hold US citizenship, serve in the military, are represented in the House of Representatives by a Resident Commissioner elected to a four-year term who does not have privileges to vote on the floor of the House, are subject to federal laws and are beneficiaries of federal aid as approved by Congress, do not vote in national elections, and pay no federal income tax (Bea, 2005, p. i).

This situation and use of the term 'Commonwealth' has led to many debates among politicians, intellectuals, and Puerto Ricans. In Spanish, the present status is 'Estado Libre Asociado,' commonly translated as 'Commonwealth'. Some observers (Anderson, 1965; Perusse, 1990) have argued that the meanings and implications of those two terms are not the same.

\section{Voicing Change, Remaining the Same}

Puerto Rico's political relationship with the US has been a continuing source of debate in Puerto Rico, the US Congress, and the United Nations. The issue revolves around whether Puerto Rico should remain a US territory (Commonwealth status), become a US state (statehood status), or become an independent country. Despite several attempts to change or enhance the situation, one needs to keep in mind that ultimately, the US Congress is the only body that can make decisions regarding the political status of Puerto Rico, as stated under the Territorial Clause.

Despite debates on the nature of the status, the relationship that Puerto Rico has with the US remains at the core of the political party system,

No one single issue stirs Puerto Rican emotions more violently than that of status. It is, in truth, the issue of issues (Lewis, 1963, p. 409).

Similarly, Anderson (1998, p. 3) writes,

It is the status problem, the unresolved problem of decolonization, which makes Puerto Rico politically so interesting. It is the context within which the vocabulary of politics is couched in Puerto Rico; in spite of attempts to assume the contrary, it tends to define the political parties themselves and how they are distinguished from each other.

In fact, the party system in Puerto Rico is built around three main parties, each representing one status option. The PPD advocates an (enhanced) Commonwealth and, following Lluch's typology, increased autonomy. The New Progressive Party (PNP) advocates Puerto Rico's admission to the US as a state (federation). The Puerto Rican Independence Party (PIP) campaigns for the independence of Puerto Rico. The PIP has never been in power and, in recent years, there has been a growing number of smaller parties (e.g. Partido del Pueblo Trabajador, Movimiento Union Soberanista, Movimiento Independentista Nacional 


\section{Vézina}

Hostosiano) that have emerged to rival the PIP. Yet, it has generally been accepted and included in political debates, as if the PIP had the same status of the other two major parties. Despite attempts from all parties in different elections to present other issues, the status issue remains the political issue in Puerto Rico. Anderson sums up the debate,

... the problem of relations between Puerto Rico and the United States is at the very centre of party politics. In a sense ... the party system internalizes this problem and expresses it in its various, potentially contradictory, 'solutions' (1965, p. 12).

Table 1: Status Options Definitions in 1967, 1993, 1998 and 2012 Plebiscites held in Puerto Rico.

\begin{tabular}{|c|c|c|c|c|c|c|}
\hline & Independence & Statehood & Commonwealth & $\begin{array}{c}\text { Territorial } \\
\text { C'wealth }\end{array}$ & $\begin{array}{c}\text { Free } \\
\text { Association }\end{array}$ & $\begin{array}{c}\text { None } \\
\text { of } \\
\text { the } \\
\text { above }\end{array}$ \\
\hline $1967 *$ & $\begin{array}{l}\text { - The } \\
\text { authorization to } \\
\text { ask Congress } \\
\text { for the } \\
\text { Independence of } \\
\text { Puerto Rico } \\
\text { from the USA. }\end{array}$ & $\begin{array}{l}\text { - The } \\
\text { authorization to } \\
\text { solicit Congress } \\
\text { for the admission } \\
\text { of Puerto Rico as } \\
\text { a state of the } \\
\text { USA. }\end{array}$ & $\begin{array}{l}\text { - The reaffirmation of the } \\
\text { C'wealth according to } \\
\text { Public Law } 600 \text { of } 1950 \\
\text { and the Joint Resolution } \\
447 \text { of } 1952 \text { as a } \\
\text { permanent autonomous } \\
\text { community associated to } \\
\text { the USA }\end{array}$ & $\mathrm{N} / \mathrm{A}$ & $\mathrm{N} / \mathrm{A}$ & $\mathrm{N} / \mathrm{A}$ \\
\hline $1993 *$ & $\begin{array}{l}\text { - The right of } \\
\text { our people to } \\
\text { govern on their } \\
\text { own land, the } \\
\text { enjoyment of all } \\
\text { powers and } \\
\text { attributes of } \\
\text { sovereignty. }\end{array}$ & $\begin{array}{l}\text { - A mandate to } \\
\text { claim the } \\
\text { integration of } \\
\text { Puerto Rico as a } \\
\text { state of the } \\
\text { Union. }\end{array}$ & $\begin{array}{l}\text { - A vote to guarantee the } \\
\text { progress and security of } \\
\text { the people to live in } \\
\text { political dignity, based on } \\
\text { the permanent union } \\
\text { between Puerto Rico and } \\
\text { the United States, } \\
\text { consecrated in a bilateral } \\
\text { agreement that can only be } \\
\text { modified by mutual } \\
\text { consent. }\end{array}$ & N/A & $\mathrm{N} / \mathrm{A}$ & N/A \\
\hline 1998* & $\begin{array}{l}\text { - The } \\
\text { recognition that } \\
\text { Puerto Rico is a } \\
\text { free republic } \\
\text { with full } \\
\text { authority on its } \\
\text { territory and its } \\
\text { international } \\
\text { relations with a } \\
\text { Constitution } \\
\text { that would be } \\
\text { the Supreme } \\
\text { Law in a } \\
\text { republican } \\
\text { system of } \\
\text { governance. }\end{array}$ & $\begin{array}{l}\text { - The integration } \\
\text { of Puerto Rico in } \\
\text { the Union of the } \\
\text { United States of } \\
\text { America as a } \\
\text { state equal in } \\
\text { rights and } \\
\text { responsibilities as } \\
\text { other states }\end{array}$ & $\mathrm{N} / \mathrm{A}$ & $\begin{array}{c}\text { - Based on } \\
\text { Territorial } \\
\text { Clause of } \\
\text { Federal } \\
\text { Constitution \& } \\
\text { Public Law } \\
\text { 600; extension } \\
\text { of sovereignty } \\
\text { of Congress } \\
\text { over the Island, } \\
\text { which has } \\
\text { delegated a } \\
\text { limited form of } \\
\text { local } \\
\text { government } \\
\text { extension of US } \\
\text { citizenship and } \\
\text { English as } \\
\text { official }\end{array}$ & $\begin{array}{l}\text { - A treaty that } \\
\text { recognize the } \\
\text { sovereignty of } \\
\text { Puerto Rico to } \\
\text { negotiate its } \\
\text { relations, that } \\
\text { would be non- } \\
\text { territorial and } \\
\text { non-colonial, } \\
\text { with the } \\
\text { United States. }\end{array}$ & $\begin{array}{l}\text { None } \\
\text { of the } \\
\text { choices } \\
\text { on the } \\
\text { ballot } \\
\text { corresp } \\
\text { ond to a } \\
\text { desired } \\
\text { status } \\
\text { option }\end{array}$ \\
\hline
\end{tabular}




\begin{tabular}{|c|c|c|c|c|c|c|}
\hline & & & & $\begin{array}{c}\text { language of } \\
\text { federal agencies } \\
\text { operating in } \\
\text { Puerto Rico. }\end{array}$ & & \\
\hline $\begin{array}{c}2012 \\
* *\end{array}$ & $\begin{array}{l}\text { - Puerto Rico } \\
\text { should become } \\
\text { a sovereign } \\
\text { nation, } \\
\text { fully } \\
\text { independent } \\
\text { from the United } \\
\text { States and the } \\
\text { United States } \\
\text { Congress would } \\
\text { be required to } \\
\text { pass } \\
\text { any necessary } \\
\text { legislation to } \\
\text { begin the } \\
\text { transition } \\
\text { into an } \\
\text { independent } \\
\text { nation of Puerto } \\
\text { Rico. }\end{array}$ & $\begin{array}{l}\text { - Puerto Rico } \\
\text { should be } \\
\text { admitted as a } \\
\text { state of the } \\
\text { United States of } \\
\text { America so that } \\
\text { all United States } \\
\text { citizens residing } \\
\text { in Puerto Rico } \\
\text { may have rights, } \\
\text { benefits, and } \\
\text { responsibilities } \\
\text { equal to those } \\
\text { enjoyed by all } \\
\text { other citizens of } \\
\text { the states of the } \\
\text { Union, and be } \\
\text { entitled to full } \\
\text { representation in } \\
\text { Congress and to } \\
\text { participate in the } \\
\text { Presidential } \\
\text { elections, and the } \\
\text { United States } \\
\text { Congress would } \\
\text { be required to } \\
\text { pass any } \\
\text { necessary } \\
\text { legislation to } \\
\text { begin the } \\
\text { transition into } \\
\text { Statehood. }\end{array}$ & $\mathrm{N} / \mathrm{A}$ & $\mathrm{N} / \mathrm{A}$ & $\begin{array}{c}\text { - Puerto Rico } \\
\text { should adopt a } \\
\text { status outside } \\
\text { of the } \\
\text { Territory } \\
\text { Clause of the } \\
\text { Constitution } \\
\text { of the United } \\
\text { States that } \\
\text { recognizes the } \\
\text { sovereignty of } \\
\text { the } \\
\text { People of } \\
\text { Puerto Rico. } \\
\text { The Sovereign } \\
\text { Free } \\
\text { Associated } \\
\text { State would } \\
\text { be based on a } \\
\text { free and } \\
\text { voluntary } \\
\text { political } \\
\text { association, } \\
\text { the specific } \\
\text { terms } \\
\text { of which shall } \\
\text { be agreed } \\
\text { upon between } \\
\text { the United } \\
\text { States and } \\
\text { Puerto Rico as } \\
\text { sovereign } \\
\text { nations. }\end{array}$ & $\mathrm{N} / \mathrm{A}$ \\
\hline
\end{tabular}

* Definitions of status options are taken from: Álvarez Rivera, Manuel. Elecciones en Puerto Rico. (2013) http://electionspuertorico.org. Eleborated details of what each vote meant is to be found there. Only the general implications are reproduced here. The translation is mine.

** The 2012 definitions are taken directly from the official ballot from the Electoral

Commission of Puerto Rico. http://www.ceepur.org/es-

pr/Documents/PapeletaModeloPlebiscito12.pdf

Puerto Rico held four plebiscites on the status question in 1967, 1993, 1998 and most recently, in 2012. In each instance, there were at least three choices on the ballot, and as many as five choices in 1998; this made securing even a simple majority almost impossible. The 1967 plebiscite was boycotted by independentist forces and the Commonwealth option won by $60 \%$. In 1993, the vote between the Commonwealth and the statehood options was close with none 
obtaining a majority, which therefore meant that the status quo was maintained. In 1998, "none of the above" received a majority of the votes. This option was advocated by Commonwealth forces due to the lack of clarity and distinction of the "Free association" and the "Limited SelfGovernment" options. In 2012, Puerto Ricans were faced with a ballot (see Appendix 1) that first asked them if the Island should continue to have its present territorial status. Then, Puerto Ricans were to decide which non-territorial status was their favoured choice, statehood, independence or a sovereign but freely associated state (an enhanced version of the present Commonwealth status, arguing that a voluntary association between Puerto Rico and the United States would be made and the terms of such association will be negotiated between two sovereign nations, much like the Cook Islands with New Zealand). The result: 54\% voted for a change to the present territorial status. This is the most interesting of the two results, showing the disapproval of Puerto Ricans towards their current situation. The results of the second part (the non-territorial options) can be presented in two ways. As it was reported by the Electoral Commission of Puerto Rico and Western Press (Associated Press among others), the statehood option won with $61 \%$ of popular support, the Sovereign Free Associated State option received $33 \%$ of the votes and the independence option, 5\% (Comision estatal de elecciones, 2012). From this, one can deduce that Puerto Rico is to become the $51^{\text {st }}$ state of the United States. However, the Nuevo Día, one of San Juan's (and Puerto Rico's) biggest newspaper, presented the results in another way, a view also share among academics and government officials from the United States, counting the votes that were left blank or that were marked by more than one option. From this perspective, no option won a majority of support, the 'statehood' option leading with $45 \%$, whereas the 'blank and spoilt' ballots accounting for over $25 \%$ (more than the $24 \%$ received for the Sovereign but Freely Associated State option) (El Nuevo Día, 2012). Blogs, forum discussions and media outlets from various constituencies decried that the 2012 plebiscite had been (once again) inconclusive. Table 1 sums up the various options and definitions presented in each plebiscite.

The plebiscites raise important questions: What is the usefulness of plebiscites if ultimately only the US Congress can change Puerto Rico's status? If Puerto Ricans really want to send a strong message to the US Congress, how, with three (or five, as in 1998) options on the ballot, could they realistically do so? Despite attempts for change, Puerto Rico's status has of yet remained the same. However, there have been Senate hearings in the months following the 2012 plebiscite. The US congress could quite likely, following these results, sponsor yet another (but, this time, binding) plebiscite that would present the three status options.

\section{The United States vs. Puerto Rico: Empire-Colonial relations}

Relationships between Puerto Rico and the US are perhaps best described as colonial. The UN General Assembly has taken Puerto Rico off its list of non-self-governing countries through Resolution 748 (VIII) in 1953 (following the Puerto Rican vote for 'Commonwealth' in 1952), but there have been repeated petitions presented to the UN to the effect that Puerto Rico effectively remains a US colony (e.g. UN Special Committee on Decolonization hearings). Puerto Ricans have been US citizens for almost a century, a status which allows them to go back and forth from the island to the mainland; yet, Puerto Ricans still feel first and foremost Puerto Ricans. The legal definition of their identity does not correspond to their self-perception as "Puerto Ricans first, and Americans second" (Duany, 2002). 
There is a Puerto Rican nation in spite of, and because of, almost five centuries of colonialism. Its presence can be attested to by the existing features of a culture that, although it has roots in different external cultural experiences, is unique ... While the political and electoral manifestations of Puerto Rican nationalism are relatively weak, a very strong current of cultural nationalism affects all formal political pronouncements (Carrión, 1993, pp. 68-69).

Similarly, Arlene Dávila argues,

The decrease in electoral support for independence, however, does not reflect a decline in nationalist identification in Puerto Rican society but rather a shift in its historical manifestation (1997, p. 25).

However, despite attempts through plebiscites to change the status of Puerto Rico, Puerto Ricans have remained divided on their island's future. Puerto Rico entered the $21^{\text {st }}$ century with a strong sense of national pride, but with a soul divided over its political status and future.

In 2000, Bill Clinton issued an Executive Order establishing the President's Task Force on Puerto Rico's Status. In its first report, tabled in 2005, the Task Force suggested that the US Constitution should only allow for three options regarding the status of the island (continued territorial status or Commonwealth, statehood, or independence). This conclusion was not innovative or contentious, but instead restated what were seen as the only options for Puerto Ricans. The Task Force's second and third reports, released in 2007 and 2011, restated the same three options, but added 'free association'. ${ }^{3}$ In those reports, the Task Force proposed a two-step plebiscite,

[A] two-plebiscite system would allow the people of Puerto Rico first to vote on the question of whether they wish to be part of the United States or wish to be independent, and then to choose between the available status options, as limited by the outcome of the first vote (Recommendation \#3, Report of the President's Task Force on Puerto Rico's Status, 2011).

Soon after the release of the Report, the then-Governor of Puerto Rico announced his commitment to hold a two-stage plebiscite on the status question, a promise he had made in the past. However, in his announcement, Governor Luis Fortuño clearly used the language of the Task Force report by saying: "We are going to file an administration bill that follows the recommendation of Page 28 of the Task Force report calling for two votes" (Caribbean Business, 2011). It comes to no surprise that the Governor (and President of the PNP), who is in favour of statehood, supports the recommendations of the Task Force. As promised, on November $6^{\text {th }} 2012$, voters in Puerto Rico decided who their next Governor would be, but also voted on their preferred status option in a two-step plebiscite. As discussed earlier, it is still unclear how Puerto Rico's status will unravel, but as Jaime Lluch points out,

\footnotetext{
${ }^{3}$ In the 2011 Report, the Task Force admits and explains the following options: "Statehood, Independence, Free Association, and Commonwealth." (Recommendation \#2, Report by the President's Task Force on Puerto Rico's Status, http://www.whitehouse.gov/administration/eop/iga/puerto-rico
} 
The results showed that $54 \%$ of the people voted No in the first question - a No vote in this context suggesting a vote for change. For the first time in their history, Puerto Ricans voted to show their disapproval of their present political status (Lluch, 2013, para. 9).

Until a solution acceptable to all parties is found, politics in Puerto Rico would remain centered around the status issue.

\section{Newfoundland and Puerto Rico: two island nations compared}

Although both Newfoundland and Puerto Rico are islands attached to a federal state, their relationships with their respective central state have been quite different. For Newfoundland, both major parties (Liberal and Progressive Conservative) have argued for and championed greater autonomy. However, it is important to note that Newfoundland politics is mostly 'leader-driven'. Political leaders (and Premiers in particular) have played the largest role. Peckford and Williams were the most prominent figures in using nationalist rhetoric to rally the people of Newfoundland behind their cause and were the strongest advocates of a decentralized federal state with more autonomy to the provinces. Both Peckford and Williams were the leaders of the Progressive-Conservative Party in the province. It could possibly be argued that the PC was the most effective party at using nationalism to promote its ends, but one can see the flaws of such an argument since similar policies were promoted by Premiers Smallwood and even Wells, both of whom were Liberals. Smallwood was a proud Newfoundlander who believed his province could be prosperous. His rhetoric was as nationalistic and provocative as Williams' was to some extent. Clyde Wells, who is infamously known for his opposition to the Meech Lake Accord, also promoted a certain form of nationalism. In his opposition to Meech Lake, Wells feared that Québec's demands would lead to asymmetrical federalism, something he strongly opposed as he was a proponent of a centralized federal state. Finally, it can be said that leaders in Newfoundland have had a tremendous impact on the rise of local nationalism.

That being said, returning to our initial hypothesis, with a party system on the island that mirrors that of the rest of Canada ${ }^{4}$, although there is great local pride, it is generally noted that Newfoundland does not want to leave Canada, but is looking for a place within it,

The recommended pathway [see the Royal Commission Report] to renewal puts forth compelling arguments on how Newfoundland and Labrador can renew and strengthen its place in Canada. Much of the success of the pathway depends on renewed political will by both the Government of Canada and the Government of Newfoundland and Labrador to embrace the concept of accommodation. It represents an unprecedented challenge to both governments to take into account the powerful set of circumstances that has faced Newfoundland and Labrador since Confederation, and to pursue a renewal strategy based on doing the right things in the right ways for the right reasons for the people of Newfoundland and Labrador (Young, 2003, p. 150).

\footnotetext{
${ }^{4}$ The only Canadian province that has a local, nationalist party that has championed sovereignty is Quebec. Interestingly, only Quebec and Newfoundland have official provincial anthems.
} 
Despite some major challenges facing both Newfoundland and Canada to define Newfoundland's place, it is worth remembering that most Newfoundlanders do not support independence. Newfoundlanders, despite their critique and "Ottawa-bashing" rhetoric, have been quite content with Confederation, citing health care, social assistance programs and equalization among its key benefits (Ryan Research, 2003). Furthermore, the most recent data available indicates that, while 12 percent of the population support independence, 75 percent of the population believes that, overall, Confederation has been a good thing for Newfoundland (Ryan Research, 2003). Although 12 percent might seem substantial (compared to the 4 to 5 percentage of votes received by the PIP in Puerto Rico), such data is not translated in Newfoundland into a distinct party system. Attempts for independentist parties in Newfoundland (e.g. the Newfoundland and Labrador First Party) have been short-lived. The impact of the party system on nationalist demands is thus indirect. Both major political parties have pushed forward demands in times of need or, most importantly, when the federal government was seen as encroaching over provincial powers.

In Puerto Rico, the party system has clearly shaped nationalism and has a direct impact on nationalist demands. The party system is built around the status issue and is quite distinct from the Democrat-Republican binarism found in the USA. The three major political parties in Puerto Rico, while advocating for different status, have used nationalism to different ends. When talking about the political parties and their use of nationalist sentiments and rhetoric, one cannot dismiss the importance of the PIP, which has been the most vigorous in using nationalism to pursue its ends. As Rubén Berríos Martínez, then President of the PIP, wrote,

Puerto Rico's heart is not American. It is Puerto Rican. The national sentiment of Puerto Ricans is entirely devoted to our patria as we call our homeland in Spanish, our language. ... For us, 'we the people' means we Puerto Ricans (1997, p. 102).

But the PIP is not the only party to make such nationalist appeals to the people. Even the PPD, the pro-Commonwealth party, has used such rhetoric. For Dávila (1997), such use goes back to the leadership of Muñoz Marin. In response to Operation Bootstrap (Puerto Rico export-led industrialization model), ${ }^{5}$ Muñoz Marin launched Operation Serenity, a program aimed at enhancing education and the arts. This operation,

... marked an important moment in the development of Puerto Rico's cultural nationalism involving a romanticization and purification of culture by reference to an idealized past (Dávila, 1997, p. 34).

In fact,

Muñoz Marin was one of the chief architects of cultural nationalism in postwar Puerto Rico ... Cultural nationalism represents a serious (though perhaps limited) attempt to assert Puerto Rico's distinctive collective identity, within the context of continued political and economic dependence on the United States (Duany, 2002, p. 17).

\footnotetext{
${ }^{5}$ Operation Bootstrap enticed investors to transfer or create manufacturing plants, offering them local and federal tax concessions, while maintaining access to American markets free of import duties. The program facilitated a shift from an agricultural to an industrial economy.
} 


\section{Vézina}

The pro-statehood party has also made use of nationalist sentiment and national identity in order to gain popular favour. In advocating for statehood, the PNP in recent years has sought to convince Puerto Ricans that, by becoming a state of the US, Puerto Rico would keep Spanish as its official language (Carrión, 1993). As Spanish is usually considered an important distinctive characteristic of the Puerto Rican nation, appealing to it is a clear example of the use of nationalism for a particular end; in this case, the push for statehood.

Briefly, it can be said that, despite internal conflicts over the status question and the marked differences among parties in Puerto Rico, all political parties have used nationalism, though for different ends. This analysis has shown that, no matter which relationship a party advocates, nationalism has an important role in Puerto Rico.

\section{Conclusion}

This paper has tried to validate the hypothesis formulated by Fazi and Hepburn. In doing so, we found empirical evidence to support the hypothesis that a different party system leads to increasing nationalist demands. Our analysis of Newfoundland and Puerto Rico has shown us that the party system in Puerto Rico is built around the status issue and has led to plebiscites claiming for a status change. In Newfoundland, where a different party system does not exist, the expression of nationalist demands has been done by all political parties upon specific circumstances (the control of natural resources, mainly oil). While no plebiscite has taken place in Newfoundland since Confederation, we agree with Summers (2001, p. 44) when she argues,

Various provincial and national surveys reveal a strong attachment to Newfoundland as a political entity, a prior loyalty to Newfoundland, not Canada, and nascent separatist sentiments. There is in Newfoundland an emergent ethnicity which could be mobilized into an independence movement.

Hence, we cannot totally validate the hypothesis with this case-study. Further research, including a greater data set of islands containing both a distinct and similar party system to their central state, would be necessary to strengthen our analysis. Furthermore, a series of questions can be raised following this initial survey. We wonder why both mainly-island provinces in Canada - Newfoundland \& Labrador and Prince Edward Island (PEI) - have not produced a different and distinct party system ${ }^{6}$. Is it because of their small populations? Or is it because there were never any real alternative national identity markers in these two provinces, represented also by the primacy of English as the spoken language? On the other hand, in Puerto Rico, the determining factor, and one that we have briefly looked at, is the historical dimension. Puerto Rico, before being a Commonwealth of the USA, was a colony of Spain for four centuries. The colonial relationship still resonates within the United States and impacts the political party system; indeed, the status question is described by many as a 'colonial' one (Pantojas-García, 2013; Lluch, 2013). Furthermore, the distinctive language (Spanish) cannot be neglected. As Fazi (2012b) reminds us the cultural dimension cannot be ignored when it comes to studying identities, especially where there is a vibrant, distinct language in place. In other words, despite our desire to focus on one aspect of islandness, many other factors will have to enter into the equation. However, we can see certain recent trends in both islands relating to nationalism. In both cases, the islands have undergone major political changes. In

\footnotetext{
${ }^{6}$ Labrador is different, and there has been a Labrador Party contesting elections there.
} 
Newfoundland, federal-provincial relations had become more tense under Williams' leadership, mainly due to Williams' strong commitment to protecting the interests of his province and not to let outsiders (such as federal government, or oil companies) make decisions on behalf of Newfoundlanders. His retirement in December 2010 came as a shock to the province. In October 2011, the Progressive-Conservatives were reconfirmed in power, although with less support than in the previous election. Throughout her term, Premier Kathy Dunderdale did not deploy similar nationalist rhetoric to claim more autonomy for the province, and her resignation in January 2014 came at a moment where she was both criticized internally and externally for her lack of public communication skills. It will remain to be seen who will revert to the use of nationalist rhetoric in Newfoundland. Meanwhile, as the 2012 results have shown, for the first time in their history, Puerto Ricans have voiced that their current status was not satisfactory. Embroiled in its own financial crisis, it remains to be seen what economic and political changes will be resorted to in Puerto Rico, and how political parties and leaders will propose national rhetoric in defining demands to the US.

\section{Acknowledgements}

This paper is based on an earlier draft which was first presented at the 2011 Canadian Political Science Association Annual Meeting. It has benefited from constructive comments from André Lecours, Luc Turgeon and Paul Hamilton, as well as questions from the audience. The author also wishes to thank the anonymous reviewers whose comments were more than helpful.

\section{References}

Anderson, R. W. (1965). Party politics in Puerto Rico. Stanford CA: Stanford University Press.

Anderson, R. W. (1998). Political parties and politics of status. Caribbean Studies, 1(1), pp. 143.

Baker, M. (2003). Falling into the Canadian lap: confederation of Newfoundland \& Canada, 1945-1949. In Collected research papers of Royal Commission on renewing and strengthening our place in Canada (pp. 33-88). St. John's NL: Government of Newfoundland \& Labrador.

Baldacchino, G. (2004). Autonomous but not sovereign? a review of island sub-nationalism. Canadian Review of Studies in Nationalism, 21(1), pp. 77-91.

Baldacchino, G. (2006). Islands, island studies, Island Studies Journal. Island Studies Journal, 1(1), pp. 3-18.

Baldacchino, G. (2009). Governance in small places: the unleashing of asymmetric federalism. In G. Baldacchino, L. Felt \& R. Greenwood (Eds.) Remote control: Governance lessons for and from small, insular and remote regions (pp. 114-134). St John's NL: ISER Press.

Baldacchino, G. (2010). Island enclaves: Offshoring strategies, creative governance and subnational island jurisdictions. Montreal QC: McGill-Queen's University Press.

Baldacchino, G., \& Hepburn, E. (2012). A different appetite for sovereignty? Independence movements in subnational island jurisdictions. Commonwealth \& Comparative Politics, 50(4), pp. 555-568. 
Bannister, J. (2003). The politics of cultural memory: themes in the history of Newfoundland and Labrador in Canada, 1972-2003. In Collected research papers of the Royal Commission on renewing \& strengthening our place in Canada (pp. 124-166). St. John's NL: Government of Newfoundland and Labrador.

Bea, K. (2005). Political status of Puerto Rico: background, options, and issues in the 109th Congress. In Congressional Research Service Report for Congress, 7-5700, RL32933.

Brubaker, R. (1996). Nationalism reframed: nationhood and the national question in the new Europe. New York: Cambridge University Press.

Cadigan, S. T. (2009). Newfoundland and Labrador: A history. Toronto ON: University of Toronto Press.

Caribbean Business. (2011). NPP Pushes for two-step status plebiscite. Retrieved from http://www.caribbeanbusinesspr.com/news03.php?nt id=55676\&ct id=1

Carrión, J. M. (1993). The national question in Puerto Rico. In E. Meléndez \& E. Meléndez (Eds.) Colonial dilemma: Critical perspectives on contemporary Puerto Rico (pp. 6775). Boston MA: South End Press.

CBC News. (2004). Canadian flags ordered down: Williams. Retrieved from www.cbc.ca/canada/newfoundland-labrador/story/2004/12/23/nf-williams-flag20041223.html

Colley, L. (1992). Britons: Forging the nation 1707-1837. New Haven CT: Yale University Press.

Comision estatal de elecciones. (2012). Papeleta modelo. Retrieved from www.ceepur.org/espr/Documents/PapeletaModeloPlebiscito12.pdf

Comision estatal de elecciones. (2012). Elecciones generales 2012 y consulta sobre el estatus político de Puerto Rico. Retrieved from div1.ceepur.org/REYDI_NocheDelEvento/index.html\#es/default/OPCIONES_NO_TE RRITORIALES ISLA.xml

Conkling, P. (2007). On islanders and islandness. The Geographical Review, 97(2), pp. 191201.

Dávila, A. M. (1997). Sponsored identities: Cultural politics in Puerto Rico. Philadelphia PA: Temple University Press.

Duany, J. (2002). The Puerto Rican nation on the move: Identities on the island and in the United States. Chapel Hill NC: University of North Carolina Press.

El Nuevo Día. (2012). Puerto Rico decide. Retrieved from resultados.puertoricodecide.com/2012/elecciones-generales/

Fazi, A. (2009). La recomposition territoriale du pouvoir: Les régions insulaires de la Méditerranée occidentale. Ajaccio, France: Albiana.

Fazi, A. (2012a). Insularity and autonomy: from a misleading equation to a new typology. In A.-G. Gagnon \& M. Keating (Eds.) Political autonomy \& divided societies: Imagining democratic alternatives in complex settings (pp.134-154). Basingstoke, UK: Palgrave Macmillan.

Fazi, A. (2012b). Les politiques de l'identité corse, ou du consensus et de ses limites. Les Cahiers du CRIDAQ, 4.

Greenfeld, L. (1992). Nationalism: Five roads to modernity. Cambridge MA: Harvard University Press.

Hepburn, E. (2010). A comparative analysis of island region autonomy. Paper presented at Canadian Political Science Association Conference, Montréal, Québec. 1-3 June. 
Hepburn, E. (2012). Recrafting sovereignty: lessons from small island autonomies? In A.-G. Gagnon \& M. Keating (eds) Political autonomy and divided societies: Imagining democratic alternatives in complex settings (pp. 118-133). Basingstoke UK: Palgrave Macmillan.

Jackson, F. L. (1986). Surviving confederation: A revised and extended version of 'Newfoundland in Canada'. St. John's NL: H. Cuff Publications.

LeDuc, L. (2003). The politics of direct democracy: Referendums in global perspective. Peterborough ON: Broadview Press.

Lewis, G. K. (1963). Puerto Rico: Freedom and power in the Caribbean. London: Merlin.

Lluch, J. (2011). Autonomism and federalism. Publius: The Journal of Federalism, 42(1), pp. 134-161.

Lluch, J. (2012). Internal variation in sub-state national movements and the moral polity of the nationalist. European Political Science Review, 4(3), pp. 433-460.

Lluch, J. (2013). The plebiscite on Puerto Rico's constitutional status: determining Puerto Rico's future. March 3. Retrieved from http://www.referendum.ed.ac.uk/the-plebisciteon-puerto-ricos-constitutional-status-determining-puerto-ricos-future/

Marland, A. (2007). The 2007 provincial election in Newfoundland and Labrador. Canadian Political Science Review, 1(2), pp. 75-85.

Martínez, R. B. (1997). Puerto Rico's decolonization. Foreign Affairs, 76(6), pp. 100-114.

Morris, N. (1995). Puerto Rico: culture, politics and identity. Westport CT: Praeger Publishers.

Pantojas-García, E. (2013). The Puerto Rico status question: can the stalemate be broken? Caribbean Journal of International Relations \& Diplomacy, 1(2), pp. 41-52.

Penney, N. (1981). The parliamentary tradition of Newfoundland. Canadian Parliamentary Review, 4(2), pp. 11-16.

Perusse, R. I. (1990). The United States and Puerto Rico. Malabar FL: Robert E. Krierger Publishing.

Ryan Research. (2003). Provincial opinion survey. Retrieved from http://www.exec.gov.nl.ca/royalcomm/research/pdf/ryan.pdf

Summers, V. A. (2001). Between a rock and a hard place: regime change in Newfoundland. In K. Brownsey \& M. Howlett (Eds.) The provincial state in Canada: Politics in the provinces and territories (pp. 23-47). Peterborough ON: Broadview Press.

Vézina, V. \& Basta, K. (2014). Nationalism in Newfoundland and Labrador. In A. Marland \& M. Kerby (Eds.) First among unequals: The premier, politics and policy in Newfoundland and Labrador (pp. 67-83). Montreal QC: McGill-Queen's University Press.

Watts, R. L. (2008). Comparing federal systems. Montreal QC: McGill-Queen's University Press.

White House. (2005). Report by the President's task force on Puerto Rico's status. Retrieved from www.independencia.net/pdf/TaskForce\%20Report StatusPR.pdf

White House. (2007). Report by the President's task force on Puerto Rico's status. Retrieved from www.justice.gov/opa/documents/2007-report-by-the-president-task-force-onpuerto-rico-status.pdf

White House. (2011). Report by the President's task force on Puerto Rico's status. Retrieved from www.whitehouse.gov/administration/eop/iga/puerto-rico

Young, V. L. (2003). Royal Commission on renewing and strengthening our place in Canada. St. John's NL: Office of the Queen's Printer. 


\section{Appendix 1: 2012 Ballot Sample on the Status Question in Puerto Rico}

\author{
PAPELETA OFICLAL \\ OFFICLAL BALLOT
}

\section{MODELO}

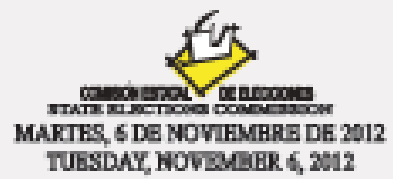

CONSULTA

PLEBISCTTE

SAMPLE

\section{CONSULTA SOBRE EL ESTATUS POLITICO DE PUERTO RICO PLEBISCITE ON PUERTO RICO POLITICAL STATUS}

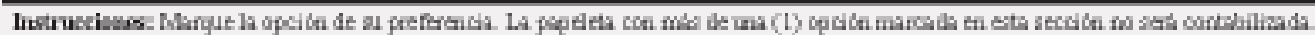

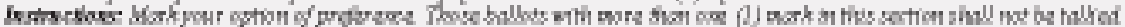

¿Está asted de acuerdo cen mantener la condición politica territorial actual?

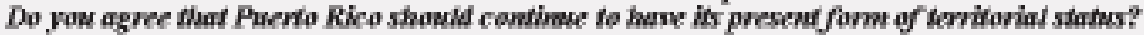

\section{Sí / Yes}

\section{No $/ N o$}

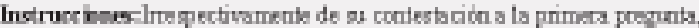
conteste cuál de las siguientes opciones no territoriales usted prefiere.

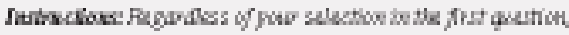
pleuse wark which of the following nou-territorial options wowid you prefer.

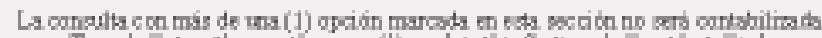

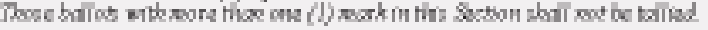

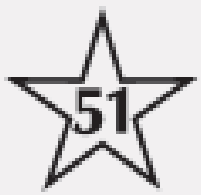

\section{Estadidad:}

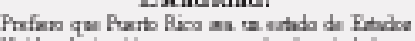

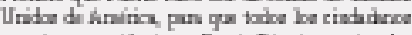

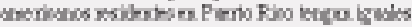

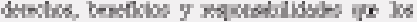

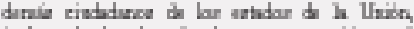

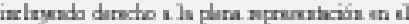

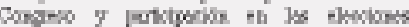

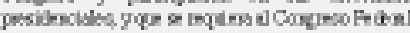

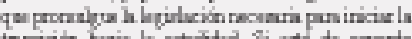
tamicita liveis be entudidud Si sati de acouda nemporil:

\section{Sertebeat:}

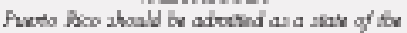

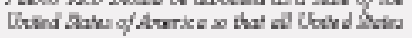

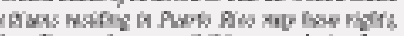

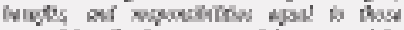
etogned by ed afoer ctinese of the state of toe

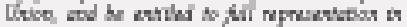

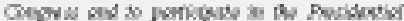

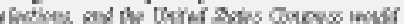

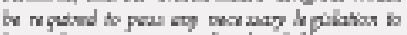

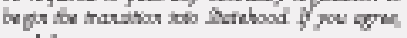
wit ix.

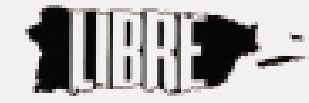

Independencia:

Anfers qu Puxra fico an wa meisin mbenca

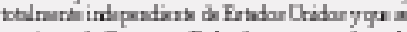

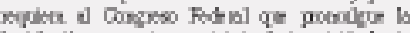

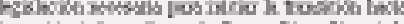

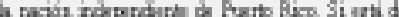
seurib raxq ang

\section{Irulependerec:}

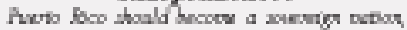

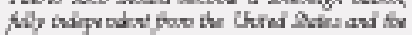

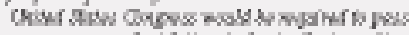

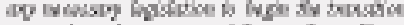

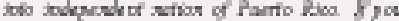
agene, nost here: 